УДК 336.66

\title{
УПРАВЛІННЯ ОБОРОТНИМИ АКТИВАМИ ПІДПРИЄМСТВА ТА ЇХ ВИДАМИ
}

\section{MANAGEMENT OF CURRENT ASSETS OF ENTERPRISES AND THEIR TYPES}

\author{
Перевозова Ірина Володимирівна \\ доктор економічних наук, профресор, \\ Івано-Франківський національний технічний університет нафрти і газу \\ ORCID: https://orcid.org/0000-0002-3878-802X \\ Павлова Галина Євгеніївна \\ доктор економічних наук, профресор, \\ Дніпровський державний аграрно-економічний університет \\ ORCID: https://orcid.org/0000-0002-1400-7348 \\ Perevozova Iryna \\ Ivano-Frankivsk National Technical Oil and Gas University \\ Pavlova Halyna \\ Dnipro State Agrarian and Economic University
}

\begin{abstract}
В статті зазначено, що управління оборотними активами становить найбільш велику частину фрінансового менеджменту у системі управління активами підприємства. На основі аналізу літературних джерел нами було розроблено загальний алгоритм управління оборотними активами підприємства, який складається 3 шести етапів та включає аналіз використання оборотного капіталу в попередньому періоді, визначення підходів до фрормування оборотних активів, їх оптимізацію, забезпечення необхідної ліквідності та збільшення рентабельності оборотних активів. Запропоновано практичний варіант покращення управління оборотними активами на прикладі запасів фрермерського господарства. Вказана пропозиція, а саме збільшення суми партії придбаних виробничих запасів зменшить не тільки суму транспортно-заготівельних витрат, але і вплине на вартість самої партії.

Ключові слова: оборотні активи, управління, структура, ефективність, виробничі запаси.
\end{abstract}

В статье отмечено, что управления оборотнимы активами занимает большую часть фринансового менеджмента в системе управления активами предприятия. На основе анализа литературных источников нами был разработан общий алгоритм управления оборотными активами предприятия, который состоит из шести этапов и включает анализ использования оборотного капитала в предыдущем периоде, определение подходов к формированию оборотных активов, их оптимизацию, обеспечение необходимой ликвидности и увеличение рентабельности оборотных активов. Предложено практичный вариант улучшения управления оборотными активами на примере запасов фермерского хозяйства. Указанное предложение, а именно увеличение суммы партии приобретенных производственных запасов уменьшит не только сумму транспортно-заготовительных расходов, но и повлияет на стоимость самой партии.

Ключевые слова: оборотные активы, управление, структура, эффрективность, производственные запасы.

For the rational functioning of an enterprise, it is necessary to effectively manage its circulating assets. The efficiency of current asset management has a major impact on the continuity of the production process and sales of manufactured products, as well as on such financial indicators as liquidity, solvency and financial stability of the enterprise. The article notes that the management of current assets occupies a large part of financial management in the asset management system of an enterprise. the basis of current assets is the production stock of the enterprise. They significantly affect the financial result of economic activity, since they occupy the largest share in the cost of an enterprise in most industries in various fields of activity. It has been established that the most significant part in the structure of current assets of the enterprise is occupied by stocks, which, in turn, include firewood and materials; unfinished virobnitstvo; ready products and goods. As such, a rational way of managing stocks is one of the tasks of managing current assets. The solution to this problem is sufficient to ensure uninterrupted operation of the viral and trading process with minimal costs for the maintenance of supplies. Based on the analysis of literature 
sources, we developed a general algorithm for managing the company's current assets, which consists of six stages and includes an analysis of the use of working capital in the previous period, determining approaches to the formation of working assets, their optimization, ensuring the necessary liquidity and increasing the profitability of working assets. A practical option for improving the management of circulating assets is proposed on the example of farm stocks. This proposal, namely an increase in the amount of the batch of purchased production stocks, will not only reduce the amount of transport and procurement costs, but will also affect the cost of the batch itself. The experience of enterprises indicates the possibility of using various methods of managing current assets, including production inventories. An improved production inventory management system of an enterprise should carry out its functions in accordance with the basic principles of material support of production using management tools that ensure its flexibility and dynamism.

Keywords: current assets, management, structure, efficiency, production stocks.

Постановка проблеми. Ефрективність фрункціонування економіки країни багато в чому залежить від ефективності фрункціонування окремих підприємств. Для раціонального функціонування підприємства необхідно ефективно управляти його оборотними активами. Ефективність управління оборотними активами здійснює основний вплив на безперервність процесу виробництва та реалізації виготовленої продукції, а також на такі фрінансові показники, як ліквідність, платоспроможність та фрінансова стійкість підприємства. Підвищення ефективності управління оборотними активами завжди відображає покращення фрінансового стану підприємства. Таким чином, вирішення питань щодо управління оборотними активами та їх видами $€$ актуальними.

Аналіз останніх досліджень і публікацій. Певний внесок у рішення і розробку теоретичних і практичних питань 3 управління оборотними активами та їх окремими видами внесли відомі вітчизняні та закордонні вчені, такі як: І.О. Бланк, М.Д. Білик, М.М. Мазаракі, В.П. Кодацький, Л.Г. Соляник, В.В. Ковальов, Є.Ф. Брігхем, Р. Брейлі, С. Майєрс, С. Росс, А. Шапіро та інші. Проте, динамічний розвиток економіки вимагає подальшого дослідження цього питання, зокрема методів та засобів покращення управління оборотними активами.

Мета дослідження. Метою дослідження $\epsilon$ аналіз сутності та ролі оборотних активів у структурі капіталу підприємства, а також обґрунтування методів покращення управління оборотними активами підприємств.

Виклад основного матеріалу дослідження. Поняття «оборотні активи» має велику кількість трактувань як у вітчизняній, так і у закордонній літературі. Відомий вчений-фрінансист М.Д. Білик у своїй монограсрії «Управління срінансами державних підприємств» визначає: «оборотні активи виробничого підприємства характеризують групу мобільних активів із періодом використання до одного року, що безпосередньо обслуговують його операційну діяльність і внаслідок високого рівня їх ліквідності мають забезпечувати його платоспроможність за поточними фрінансовими зобов'язаннями» [1].

Згідно 3 П(С)БО 2 «Баланс», оборотні активи - це грошові кошти та їх еквіваленти, не обмежені у використанні, а також інші активи, призначені для реалізації чи споживання протягом операційного циклу чи 12-тьох місяців з дати балансу.

Науковці-фрінансисти дають різну класифрікацію для поділу оборотних активів на групи. Проте, більшість з них поділяють оборотні активи на наступні групи (рис. 1).

Управління оборотними активами становить найбільш велику частину фрінансового менеджменту у системі управління активами підприємства. Це пов'язано 3 існуванням великої кількості елементів активу, що срормуються за рахунок оборотного капіталу, необхідних для індивідуалізації управління. Важливість виявляється і високою динамікою трансформації видів оборотних активів; високою роллю в забезпеченні платоспроможності, рентабельністю та інших цільових результатів фрінансової діяльності підприємства.

Як правило, найбільш вагому частину у структурі оборотних активів підприємства займають запаси, які, в свою чергу включають сировину та матеріали; незавершене виробництво; готову продукцію та товари. Саме тому, пошук раціонального способу управління запасами $\epsilon$ одним 3 завдань управління оборотними активами. Вирішення цього завдання дозволяє забезпечити безперервність виробничого і торгівельного процесу при мінімальних витратах на утримання запасів.

Проаналізувавши дослідження вчених, нами було розроблено алгоритм управління оборотними активами підприємства, який $€$ стандартизованим для усіх підприємств, незалежно від розмірів, фрорм власності та галузі фрункціонування (рис. 2). 


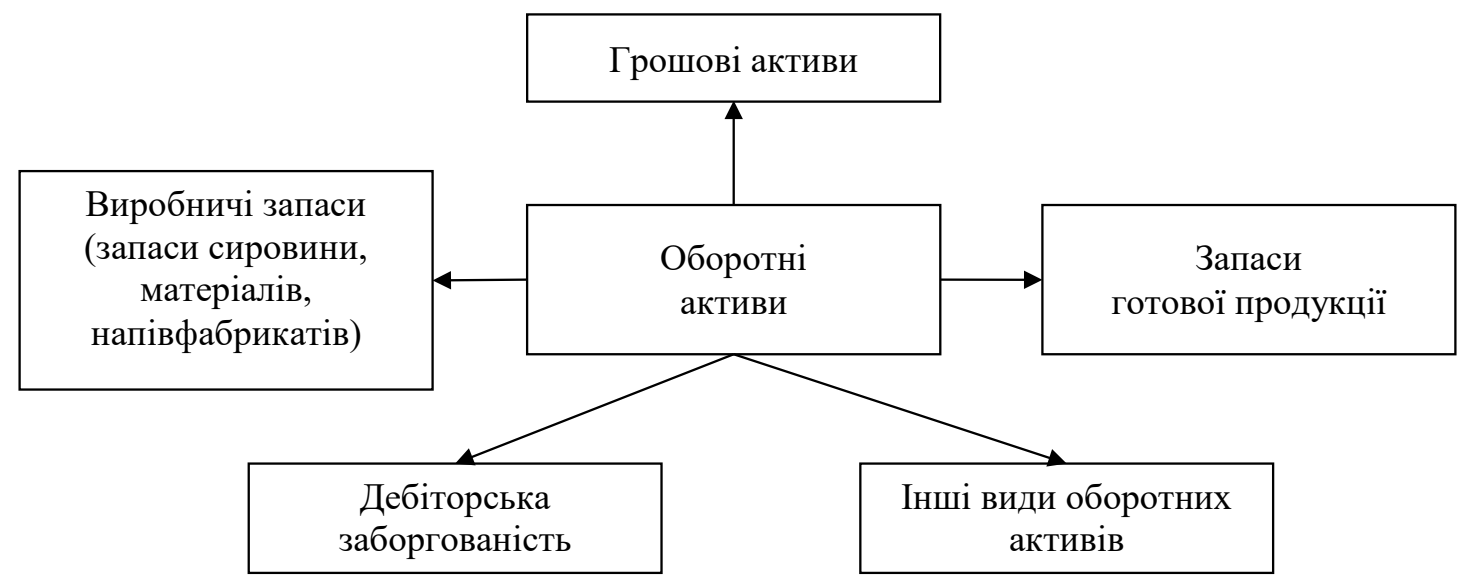

Рис. 1. Класифрікація оборотних активів

Джерело: розроблено авторами на основі [1; 3; 4]

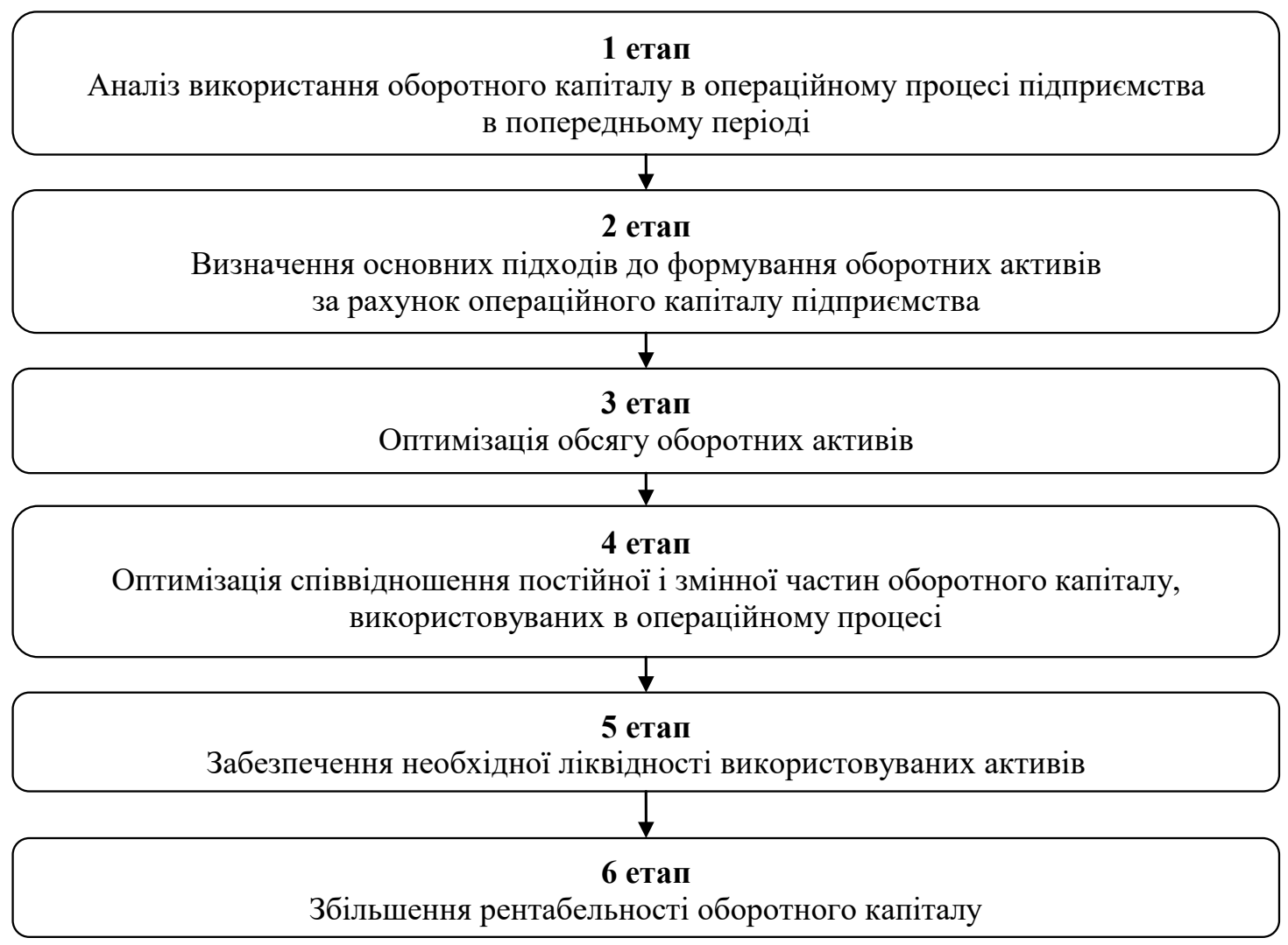

Рис. 2. Алгоритм управління оборотними активами підприємства

Джерело: розроблено авторами на основі [1-8]

На першому етапі проводиться аналіз фрінансової звітності підприємства, а саме динаміки загального обсягу оборотного капіталу, динаміки складу оборотних активів підприємства, сорормованих за рахунок оборотного капіталу. Аналіз складу оборотних активів підприємства за окремими їх видами дозволяє оцінити рівень їх ліквідності.

На другому відбувається визначення основних підходів до фрормування оборотних активів за рахунок операційного капіталу підприємства. Теорія фрінансового менеджменту розглядає три основні підходи до формування оборотних активів підприємства, а саме:

- помірний підхід - спрямований на забезпечення повного задоволення поточної потреби в усіх видах оборотних активів i створення їх нормованих страхових розмірів;

- консервативний підхід - передбачає створення високих розмірів резервів 
оборотного капіталу на випадок непередбачених складнощів у забезпеченні підприємства сировиною і матеріалами, погіршення умов виробництва, затримки інкасації дебіторської заборгованості і т.д.;

- агресивний підхід - полягає в мінімізації усіх фрорм страхових резервів за окремими видами цих активів.

На третьому етапі відбувається оптимізація обсягу оборотних активів. Така оптимізація має виходити 3 визначеного типу політики формування оборотних активів, забезпечуючи заданий рівень співвідношення ефективності і ризику використання оборотного капіталу. Оптимізація співвідношення постійної і змінної частин оборотного капіталу, використовуваних в операційному процесі складає четвертий етап.

Нап'ятому етапі відбувається забезпечення необхідної ліквідності використовуваних активів, сфрормованих за рахунок оборотного капіталу.

Ha заключному, шостому, етапі забезпечується збільшення рентабельності оборотного капіталу. Його розмір повинен генерувати певний прибуток при його використанні у виробничо-збутовій діяльності.

Зазначений алгоритм $€$ загальними для усіх видів оборотних активів. Задля отримання більш спеціалізованої та практичної індормації, слід аналізувати управління оборотними активами різних видів. Адже, цілі і характер управління окремими видами оборотних активів, сорормованого за рахунок операційного капіталу, мають суттєві відмінні риси.

Виробничі запаси $є$ одними з найважливіших на підприємстві, тому й документальне осрормлення надходження, наявності і витрачання зазначених ресурсів $€$ досить складним процесом, адже структура документообігу має бути такою, щоб забезпечувати вчасне надходження необхідної інформації як для обліку, так і контролю руху матеріальних цінностей та оперативного управління ним.

Досвід підприємств свідчить про можливості застосування різних методів управління оборотними активами, у тому числі виробничими запасами. Удосконалена система управління виробничими запасами підприємства повинна здійснювати свої фрункції відповідно до основних принципів матеріального забезпечення виробництва 3 використанням управлінських інструментів, які забезпечують іiї гнучкість і динамічність. Ефрективне фрункціонування системи управління запасами вимагає взаємодії і координації всіх іiі еле- ментів шляхом створення раціональної організації при наявності необхідних інструментів впливу на процеси із залученням аналітичних методів, що дозволяє оцінити стан системи в будь-який час і забезпечити необхідну ефективність процесів формування і використання ресурсів підприємства.

Для забезпечення ритмічності виробництва необхідно мати економічно обґрунтовані запаси матеріальних ресурсів, оскільки їх надлишок сприяє уповільненню обіговості коштів, а нестача здатна порушити безперервність виробничого процесу, викликати простої в роботі обладнання, збільшити собівартість продукції тощо. Ефективне управління матеріальними запасами передбачає аналіз існуючих моделей планування запасів і вибір тієї з них, яка забезпечувала б оптимальне інвестування коштів у виробничі запаси. Тому виникає необхідність визначення того необхідного рівня запасів, який дозволить мінімізувати витрати на їх придбання й утримання.

Надамо конкретні практичні рекомендації з удосконалення управління оборотними активами, а саме виробничими запасами на прикладі ФГ «Агрос» (Дніпропетровська область). Оскільки запаси в процесі виробництва переносять свою вартість на виготовлений продукт, то, очевидно, що чим нижчими будуть витрати на їх придбання й утримання, тим нижчою буде собівартість виробу i, відповідно, вищою ефективність виробництва.

Розробимо таку систему управління виробничими запасами для ФГ «Агрос» при якій, 3 одного боку, зменшуються кошти по організації постачань, збереженню запасів і скорочуються витрати від іммобілізації оборотних коштів, а з іншого боку, мінімізуються додаткові витрати внаслідок десріциту необхідними матеріалами.

Дані ФГ «Агрос» за 2020 рік свідчать, що протягом року підприємство здійснило 80 поставок виробничих запасів; вартість придбаних запасів складає 4778116,12 грн., а сума транспортно-заготівельних витрат (далі - ТЗВ) 35116,72 грн.; середній відсоток ТЗВ на гривню придбаних виробничих запасів складає 0,73\%; в середньому сума однієї поставки запасів складала 59726,45 грн., а суми ТЗВ - 438,96 грн.

Якщо проаналізувати структуру транспортно-заготівельних витрат можна дійти до висновку, що вони складаються з наступних елементів: оформлення документів постачальником - 31\%; витрати на оплату залізничних та автотранспортних послуг - 34\%; 
Таблиця 1

Розрахунок транспортно-заготівельних витрат при зменшенні кількості поставок

\begin{tabular}{|c|c|c|c|c|c|}
\hline \multirow[b]{2}{*}{ Найменування ТЗВ } & \multirow[b]{2}{*}{$\begin{array}{l}\text { Poзмip } \\
\text { T3B, \% }\end{array}$} & \multicolumn{2}{|c|}{80 поставок } & \multirow{2}{*}{$\begin{array}{c}32 \\
\text { поставки } \\
\text { Загальний } \\
\text { розмір } \\
\text { TЗВ, грн. }\end{array}$} & \multirow[b]{2}{*}{$\begin{array}{l}\text { Економія, } \\
\text { грн. }(+,-)\end{array}$} \\
\hline & & $\begin{array}{c}\text { Загальний } \\
\text { розмір } \\
\text { ТЗВ, грн. }\end{array}$ & $\begin{array}{c}\text { TЗВ на } \\
1 \text { поставку, } \\
\text { грн. }\end{array}$ & & \\
\hline $\begin{array}{l}\text { Оформлення документів } \\
\text { постачальником }\end{array}$ & 31 & 10886,18 & 136,08 & $\begin{array}{l}136,08 \times 32= \\
=4354,47\end{array}$ & 6531,71 \\
\hline $\begin{array}{l}\text { Витрати на оплату залізничних } \\
\text { та автотранспортних послуг }\end{array}$ & 34 & 11939,68 & 149,25 & 11939,68 & - \\
\hline $\begin{array}{l}\text { Витрати на страхування } \\
\text { вантажів }\end{array}$ & 24 & 8428,01 & 105,35 & 8428,01 & - \\
\hline $\begin{array}{l}\text { Витрати на супроводження } \\
\text { вантажів }\end{array}$ & 11 & 3862,84 & 48,29 & $\begin{array}{l}48,29 \times 32= \\
=1545,14\end{array}$ & 2317,7 \\
\hline Всього & 100 & 35116,72 & 438,96 & 26267,3 & 8849,41 \\
\hline
\end{tabular}

витрати на страхування вантажів - 24\%; витрати на супроводження вантажів - $11 \%$.

Таким чином, серед перелічених витрат, витрати на оформлення документів та супроводження вантажів мають постійний характер і не залежать від розміру партії поставки (42\%). Витрати на страхування та оплату залізничних і автотранспортних послуг мають змінний характер, оскільки напряму залежать від вартості придбаних виробничих запасів (58\%).

Тому збільшення партії придбання виробничих запасів зменшить суму ТЗВ на розмір постійних витрат. Запас фрінансової стійкості ФГ «Агрос» дозволяє наявність залишків запасів на кінець року, без погіршення фрінансового стану підприємства. Вартість партії купованих запасів збільшити у 4 рази. Проте використати весь запас фрінансової стійкості підприємства на придбання запасів $є$ недоцільним, оскільки необхідно враховувати інші надзвичайні ситуації, котрі можуть виникнути на підприємстві і які будуть потребувати негайної ліквідності. Тому пропонується збільшити вартість партії запасів у 2,5 рази, що зменшить кількість поставок з 80 до 32 на рік. Розрахунок транспортно-заготівельних витрат при зменшенні кількості поставок наведений в таблиці 1.
Дані таблиці 1 свідчать, що збільшення суми партії придбаних запасів та зменшення їх кількості економить ФГ «Агрос» за рік 8849,41 грн. Скорочення відбудеться за елементом «Офрормлення документів» - на 6531,71 грн. та елементом «Витрати на супроводження» - на 2317,7 грн. Збільшення суми партії придбаних виробничих запасів зменшить не тільки суму транспортно-заготівельних витрат, але і вплине на вартість самої партії. В реальній діловій практиці чим більше замовляє покупець, тим менше він сплачує за рахунок надання знижок.

Висновки. Складність в управлінні оборотними активами залежить від таких умов, як: обсяг оборотного капіталу, що використовується в операційному процесі; різні види активів, що фрормуються за рахунок обсягу оборотного капіталу; прискорення обороту капіталу і забезпечення постійної платоспроможності підприємства тощо. Узагальнення особливостей управління оборотними активами показало, що від якості управління оборотними активами буде залежати платоспроможність господарюючого суб'єкта, рівень його рентабельності, срормування можливостей роботи в непередбачуваних ситуаціях, масштабність та рівень виробництва і кінцевої реалізації продукції.

\section{СПИСОК ВИКОРИСТАНИХ ДЖЕРЕЛ:}

1. Білик М.Д. Управління фрінансами державних підприємств. Київ : «Знання», КОО, 1999. 312 с.

2. Власова Н.О. та ін. Управління оборотними активами в підприємствах роздрібної торгівлі : монографія. Харків : ХДУХТ, 2014. 258 с.

3. Єпіфанова І.Ю., Джеджула В.В. Фінансовий аналіз та звітність : практикум. Вінниця : ВНТУ, 2017. 143 c.

4. Застрожніков А.Г., Застрожнікова І.В. Місце і роль фермерських господарств в системі агробізнесу. Збірник наукових праць Таврійського державного агротехнологічного університету (економічні науки). 2010. № 2. C. 106-116. 
5. Перевозова І.В., Янчишин А.С., Шишковський С.В. Достовірність інформації про необоротні активи, які утримуються для продажу, у контексті детінізації господарської діяльності підприємств України. Актуальні проблеми розвитку економіки регіону. 2011. Вип. 7(2). С. 109-113.

6. Крамаренко В.І., Холод Б.І. та ін. Управління ресурсами підприємства : навч. посібник. Київ : Центр навчальної літератури, 2017. 288 с.

7. Кодацький В.П. Шляхи ефективного управління оборотними активами промислових підприємств. Актуальні проблеми економіки. 2010. № 4. С. 271-274.

8. Павлова Г.Є., Приходько І.П., Тютюнник Я.В. Облікове забезпечення операцій з надходження та використання оборотних активів. Науковий вісник Ужгородського національного університету. 2018. Вип. 20(2). С. 147-150.

\section{REFERENCES:}

1. Bilyk, M.D. (1999). Upravlinnia financamy derzhavnykh pidpryiemctv [Financial management of state enterprises]. Kyiv: Znannia. (in Ukrainian)

2. Vlasova, N.O. \& other (2014). Upravlinnia oborotnymy aktyvamy $v$ pidpryiemstvakh rozdribnoi torhivli [Management of current assets in retail enterprises]. Kharkiv: KhDUKhT. (in Ukrainian)

3. Yepifanova, I.Yu. \& Dzhedzhula, V.V. (2017). Finansovyj analiz ta zvitnist': praktykum [Financial analysis and reporting: a workshop]. Vinnytsia: VNTU. (in Ukrainian)

4. Zastrozhnikov, A.H. \& Zastrozhnikova, I.V. (2010). Mistse i rol' fermers'kykh hospodarstv v systemi ahrobiznesu [Theplace and role of farms in the agribusiness system]. Zbirnyk naukovykh prats' Tavrijs'koho derzhavnoho ahrotekhnolohichnoho universytetu (ekonomichni nauky) - Collection of scientific works of the Tavriya State Agrotechnological University (economic sciences), 2, 106-116. (in Ukrainian)

5. Perevozova, I.V., Yanchyshyn, A.S. \& Shyshkovs'kyj, S.V. (2011). Dostovirnist' informatsii pro neoborotniaktyvy, iakiutrymuiut'siadliaprodazhu, u konteksti detinizatsii hospodars'koi diial'nosti pidpryiemstv Ukrainy [Reliability of information on non-current assets held for sale in the context of de-shadowing of economic activity of Ukrainian enterprises]. Aktual'ni problem rozvytku ekonomiky rehionu - Current problems of economic development of the region, 7(2), 109-113. (in Ukrainian)

6. Kramarenko, V.I., Kholod, B.I. \& other (2017). Upravlinnia resursamy pidpryiemstva: navch. posibnyk [Enterprise resource management: the textbook]. Kyiv: Tsentr navchal'noi literatury. (in Ukrainian)

7. Kodats'kyj, V.P. (2010). Shliakhy efektyvnoho upravlinnia oborotnymy aktyvamy promyslovykh pidpryiemstv. Aktual'ni problem ekonomiky - Current economic problems, 4, 271-274. (in Ukrainian)

8. Pavlova, H.Ye., Prykhod'ko, I.P. \& Tiutiunnyk, Ya.V. (2018). Oblikove zabezpechennia operatsij z nadkhodzhennia ta vykorystannia oborotnykh aktyviv [Accounting fortransaction sontherecei ptanduse of currentassets]. Naukovyj visnyk Uzhhorods'koho natsional'noho universytetu - Scientific Bulletin of Uzhhorod National University, 20(2), 147-150. (in Ukrainian) 